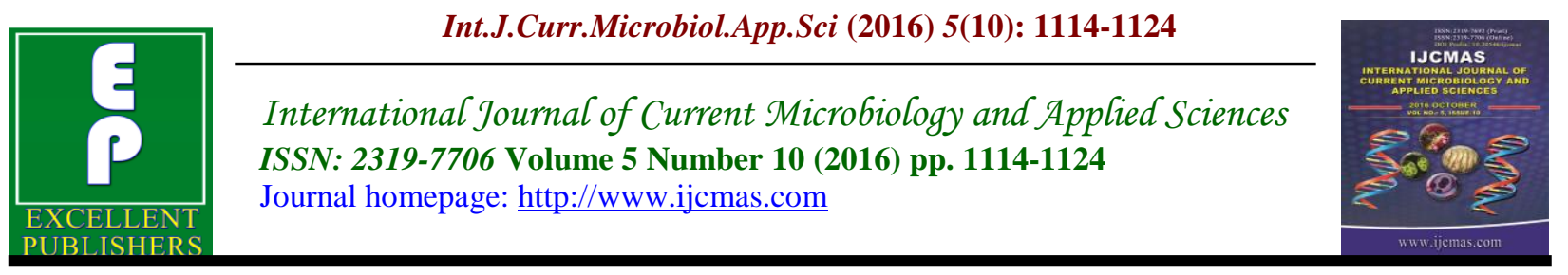

Original Research Article

http://dx.doi.org/10.20546/ijcmas.2016.510.117

\title{
Rapid Confirmation and Molecular Identification of Alkaline Protease Producing Aspergillus awamori through Submerged Fermentation
}

\author{
Radhika Pilli $^{1}$ and K.G. Siddalingeshwara ${ }^{2^{*}}$ \\ ${ }^{1}$ Research and Development Centre, Bharathiar University, Coimbatore, India \\ ${ }^{2}$ Scientific and Industrial Research Centre, Bangalore, India \\ *Corresponding author
}

\begin{abstract}
A B S T R A C T
\section{Keywords}

Alkaline protease, Molecular confirmation, Casein and Submerged fermentation.

\section{Article Info}

Accepted:

30 September 2016

Available Online:

10 October 2016

Recent years have witnessed a phenomenal increase in the use of enzymes as industrial catalysts. Proteases constitute a very large and complex group of enzymes, widely utilized in a host of industries. Industrially important efficient alkaline protease producer was isolated from soil samples collected from different regions of Bangalore. Among the 25 isolates Aspergillus awamori KGSR 12 evolved as an potential protease producer by plate assay method and it showed $1.2 \mathrm{~cm}$ diameter, $46.15 \%$ hydrolysis. The protease were confirmed by TLC method by Rf value i.e 0.84 . The molecular tool used for identification of Aspergillus awamori KGSR 12 and also optimum percentage of hydrolysis $(0.5 \%)$ were determined.
\end{abstract}

\section{Introduction}

Alkaline proteases are the proteases which have proteolytic activity at $\mathrm{pH}$ range of 8 to 14. Due to its stability at high alkaline conditions, alkaline proteases were found its great interest in physiological, industrial, biotechnological and economical applications (Maurer, 2004; Lin et al.,2006; Saeki et al., 2007; Shivasharana and Naik, 2012; Gomaa, 2013; Lakshmi et al., 2014). They are used in detergent industry, textile industry, tanning, leather processing, silk gumming, food processing, pharmaceutical industry, silver recovery, resolution of amino acid mixtures, waste treatment or bioremediation, biotransformation, feather processing (Adler-Nissen, 1986; Noutand Rombouts, 1990; Fujiwara et al., 1991; Pasupuleti, 1998, 2005; Rao et al., 1998; Ota et al., 1999; Kristinsson and Rasco, 2000; Nakiboglu et al., 2001; Garcia-Carreno et al., 2002;Gupta et al., 2002; Freddi et al., 2003;Lin et al., 2006; Bhaskar et al., 2007; Ma et al., 2007; Sareen et al., 2008; Jellouli et al., 2009; Pasupuleti and Demain, 2010; Romsomsa et al., 2010; Shankar et al., 2010; Nasri et al., 2011; Johnny and Chinnammal, 2012; Shivasharana and Naik, 2012; Feng et al., 2013; Gomaa, 2013; Jisha 
et al., 2013; Kalantzi et al, 2013; Sanatan, et al., 2013; Anju et al., 2014; Lakshmi et al., 2014; Nosenko et al., 2015; Antony and Chinnamal, 2015; Wisuthiphaet and Kongruang, 2015; Pilli and Siddalingeshwara, 2016; Verma et al., 2016).

Alkaline proteases are produced by all microorganisms like bacteria, fungi and actinomycetes which are not only alkalophilic or halophilic habitats but also non-alkalophilic habitats (Horikoshi, 1990; Grant and Jones, 2000; Gomaa, 2013).Though primarily commercial alkaline proteases are produced by bacteria, predominantly Bacillus sp., fungi are also found its place due to its easy, safe and economic enzyme recovery processing(Gupta et al., 2002; Bhaskar et al., 2007; Sareen et al., 2008; Lakshmi et al., 2014).

Thus it is desirable to search for the new alkaline proteases with novel properties produced by filamentous fungi. In this paper we found that fungi isolated from environmentally stresses, non-alkalophilic soil also could produce an alkaline protease which can exhibit vast range of alkalinity which is found to be the major criteria for the above industrial applications.

This paper highlights on the isolation, screening and molecular identification of the Aspergillus awamori and also confirmation of protease production by thin layer chromatography were employed and also an attempt of percentage of casein hydrolysis were also carried out.

\section{Materials and Methods}

\section{Sample}

Soil samples were selected for the isolation of desired fungi. The soil samples were taken from different regions of Bangalore $\left(12^{0} 59^{\prime} \mathrm{N}\right.$ latitude and $77^{0} 35^{\prime} \mathrm{E}$ longitude) of Karnataka.

\section{Isolation and screening of protease producing fungi}

Aspergillus awamori (Plate-1) were isolated from the soil sample on CzapekDox agar(CZA) medium. CZA medium composition is as follows. Glucose, 30; $\mathrm{NaNO}_{3}, 2 ; \mathrm{K}_{2} \mathrm{HPO}_{4}, 1 ; \mathrm{MgSO}_{4}, 0.5 ; \mathrm{KCl}$, 0.5; $\mathrm{FeSO}_{4}, 0.010$; Agar, 15 and $\mathrm{pH} 6.5(\mathrm{~g} / \mathrm{L}$ Distilled water), followed serial dilution (Walksman, 1927) and spread plate method (Cappuccino and Sherman, 2002). The isolated strains were screened for their protease production by plate assay.

The screening medium is as follows. Glucos e, 2 ; skim milk, 0.5 or casein, $0.5 ; \mathrm{KH}_{2} \mathrm{PO}_{4}, 1$. $52 ; \mathrm{KCl}, 0.52 ; \mathrm{MgSO}_{4} .7 \mathrm{H}_{2} \mathrm{O}, 0.52 ; \mathrm{CuNO}_{3} .3$ $\mathrm{H}_{2} \mathrm{O}$, trace; $\mathrm{ZnSO}_{4} .7 \mathrm{H}_{2} 0$, trace; $\mathrm{FeSO}_{4}$, trace; agar, 20.0 and $\mathrm{pH}-5.0$ (g/L distilled water). The clear zone was observed around the colony at regular intervals of time and measured the diameter of clear zoneand calculated percentage of hydrolysis. Aspergillus awamori were showed (Plate-2) the best zone of clearance and has produced the high percentage of hydrolysis was considered for further studies.

\section{Rapid Confirmation of Protease by Thin layer chromatography (TLC)}

The samples were withdrawn periodically at $24 \mathrm{~h}$ in aseptic condition. The extract was filtered through Whatman filter No.1. The clear extract was centrifuged at 2000- 3000 rpm for $15 \mathrm{~min}$, supernatant were used as enzyme preparation. Thus prepared crude enzyme was used for TLC.

The protease production of Aspergillus awamori KGSR12 was confirmed (Plate-3) 
by subjecting the enzyme extract to thin layer chromatography (TLC). Here the separation and identification of amino acid i.e., tyrosine is a hydrolysed product were carried out by thin layer chromatography technique by using silica gel $\mathrm{G}$ and saturated phenol with water used as a solvent system.Rf values were calculated.

\section{Molecular identification of fungal strain}

The fungal strainAspergillus awamori KGSR12 was identified morphologically (Plate-4), microscopically (Plate-5) and molecular level to confirm its identity.

On CZA plate:Growth rate is rapid and texture of colonies varies from downy to powdery and is produced radial fissures in the agar. Surface colony is initially white becoming yellow to green colour with conidial production while reverse is pale coloured and medium turned orange colour gradually.

\section{Preparation of culture for colony PCR}

The fungal strain was grown on Capek-Dox agar slant at $30^{\circ} \mathrm{C}$ for 5 days. This freshly prepared culture was ready for the colony PCR for the identification of the strain.

\section{PCR amplification}

To avoid any laboratory contamination, the PCR was performed on colonies picked directly from the agar slant culture. The 5.8ITS(internal transcribed spacer)region was amplified by PCR using universal fungal primers ITS 1 F 5'-TCCGTAGGTG AACCTGCGG-3'and ITS4 R 5'-TCCTC CGCTTATTGATATGC-3' with amplicon of 600bp (White et al., 1990; Lv et al., 2012; Shilpa et al., 2016). PCR reactions were performed in a total volume of $50 \mu \mathrm{l}$ of $0.2 \mathrm{ml}$ thin walled PCR tube. The composition contained $33 \mu \mathrm{l}$ nuclease free water, 1 pick of colony from plate, $2.0 \mu \mathrm{l}$ of Forward Primer $(10 \mu \mathrm{M}), 2.0 \mu \mathrm{l}$ of Reverse Primer $(10 \mu \mathrm{M}), 10 \mu \mathrm{l}$ of $10 \mathrm{X}$ Reaction buffer, $2 \mu \mathrm{l}$ of dNTP Mix $(10 \mathrm{mM})$ and $1 \mu \mathrm{l}$ of Taq DNA polymerase $(2.5 \mathrm{U} / \mu \mathrm{l})$. The amplification reactions were carried out in a Master cycler ${ }^{\circledR}$ Thermocycler using a PCR program (Phalip et al., 2004; Lv et al., 2012; Shilpa et al., 2016).as $10 \mathrm{~min}$ of initial denaturation at $95^{\circ} \mathrm{C}, 1 \mathrm{~min}$ of denaturation at $94^{\circ} \mathrm{C}, 1 \mathrm{~min}$ of annealing at $56^{\circ} \mathrm{C}, 1 \mathrm{~min}$ of extension at $72^{\circ} \mathrm{C}$ and $10 \mathrm{~min}$ of final extension at $72^{\circ} \mathrm{C}$. The following program was repeated from 1 min of denaturation at $94^{\circ} \mathrm{C}$ to $1 \mathrm{~min}$ of extension at $72^{\circ} \mathrm{C}$ for 35 cycles. The PCR products from ITS gene PCR reactions were purified to remove unincorporated dNTPS and primers before sequencing using PCR purification kit (GENEI GEL ELUTION KIT).

\section{Sequencing}

Both strands of the rDNA region amplified by PCR were sequenced by automated DNA sequence -3037xl DNA analyzer from Applied Biosystems using BigDye ${ }^{\circledR}$ Terminator v3.1 cycle sequencing Kit (Applied Biosystems). Sequence data were aligned and dendrograms were generated using Sequence analysis software version 5.2 from applied biosystems. The sequences obtained for plus and minus strands were aligned using appropriate software prior to phylogenetic analysis.

\section{Phylogenetic analysis}

Sequences were compared to the nonredundant NCBI(National Center for Biotechnology Information) database using BLASTN (Nucleotide Basic Local Alignment Search Tool) (http://blast. ncbi.nlm.nih.gov/Blast.cgi), with the default settings used to find sequences closest to 
each other. The Expected value and e values were noted for the most similar sequences. Ten similar neighbors were aligned using CLUSTAL W2. The multiplealignment file thus obtained was then used to create a Phylogram using the MEGA5 software.

Hydrolysis of casein at different conc. by A. awamori

Skimmed milk agar plates were prepared with different concentrations of skimmed milk (Amul milk powder) as $0.25 \%, 0.5 \%$, $0.75 \%$ and $1.0 \%$. They were incubated at $30^{\circ} \mathrm{C}$ and observed for the clear zone at regular intervals of time. The percentage of hydrolysis was calculated.

\section{Results and Discussion}

\section{Fungal isolates}

In the present study,twenty five fungal strains were isolated from the different environmentally stress soil samples. The potential strains were selected based on clear zone around the colony by plate assay. The results from plate assay were presented in plate -2 . Results revealed that $46.15 \%$ of the isolates showed hydrolysis on casein agar plates. Therefore, for the convenience, $46.15 \%$ of protease producing fungal isolates was grouped on the basis of zone of diameter they exhibited.

According to Siddalingeshwara and Lingappa (2010). According to this segregation (Plate-5), Aspergillus awamori KGSR12 exhibited the higher zone of diameter $1.2 \mathrm{~cm}$ and considered as potential strain for protease production among the strains isolated from the soil. So the fungal strain KGSR12 was selected for the further studies (Plate-1, 2).

\section{Confirmation of protease production through TLC}

The conformational studies by using Thin Layer Chromatography reported that $\mathrm{Rf}$ value of the crude enzyme was 0.84 while the tyrosine standard reported 0.88 .

\section{Molecular identification}

The ITS1 and ITS4 primers were used to amplify the ribosomal region which includes the non-coding ITS1 and ITS2 and the 5.8 rRNAgene (White et al. 1990; Lee and Taylor, 1992 andLv et al., 2012). The amplified ITS regions were run on $1.0 \%$ Agarose gel electrophoresis showed PCR product of approx. 600bp and represented (Plate-6).

Plate.1 Aspergillus awamori

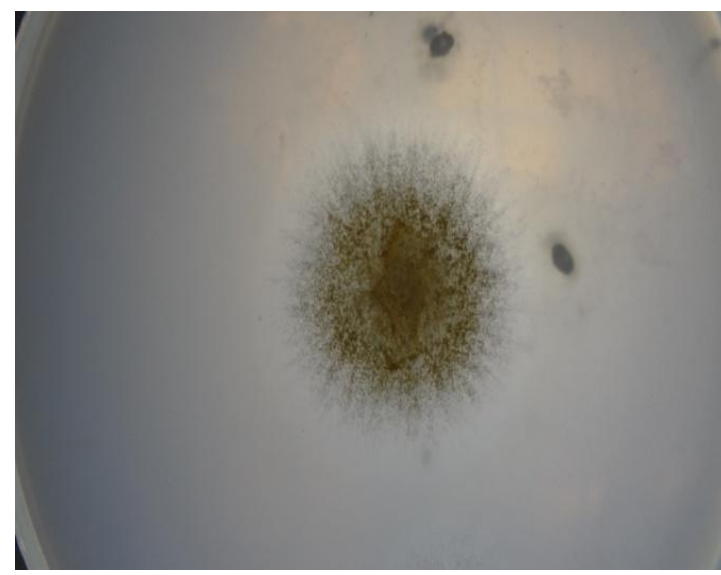


Plate.2 Screening of Protease producer by plate assay

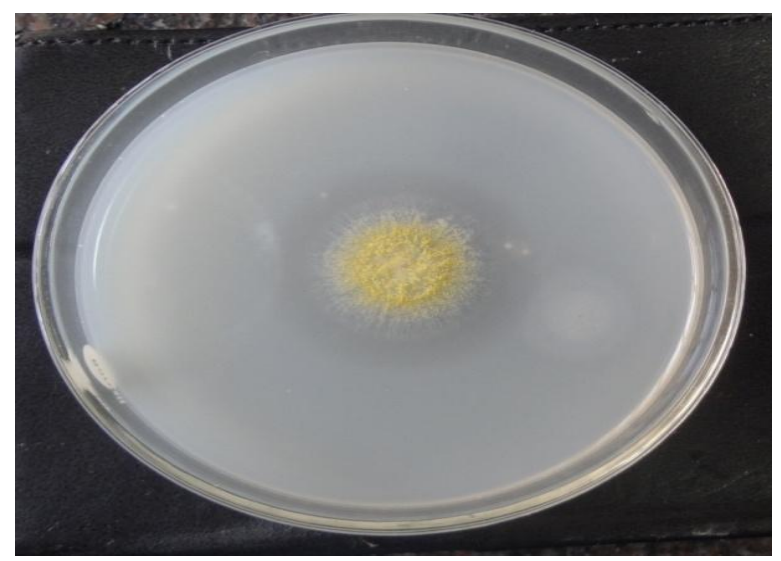

Plate.3 TLC Plate for confirmation of protease

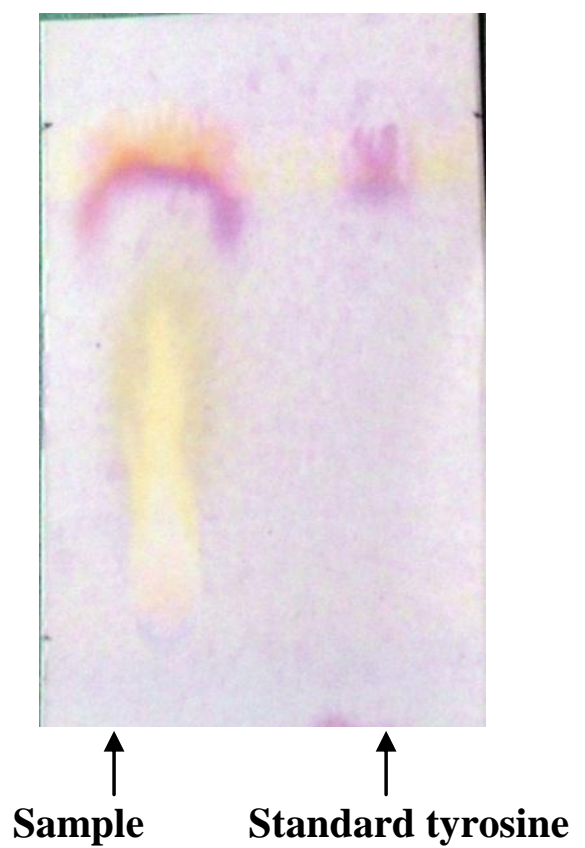

Plate.4 Microscopic view of Aspergillus awamori

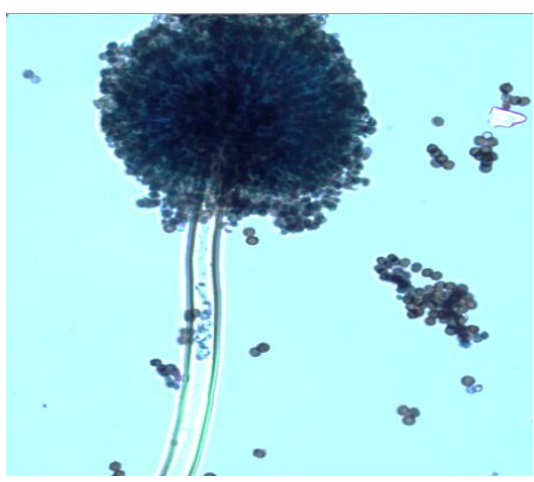


Plate.5 Segregation of fungal isolates based on protease production

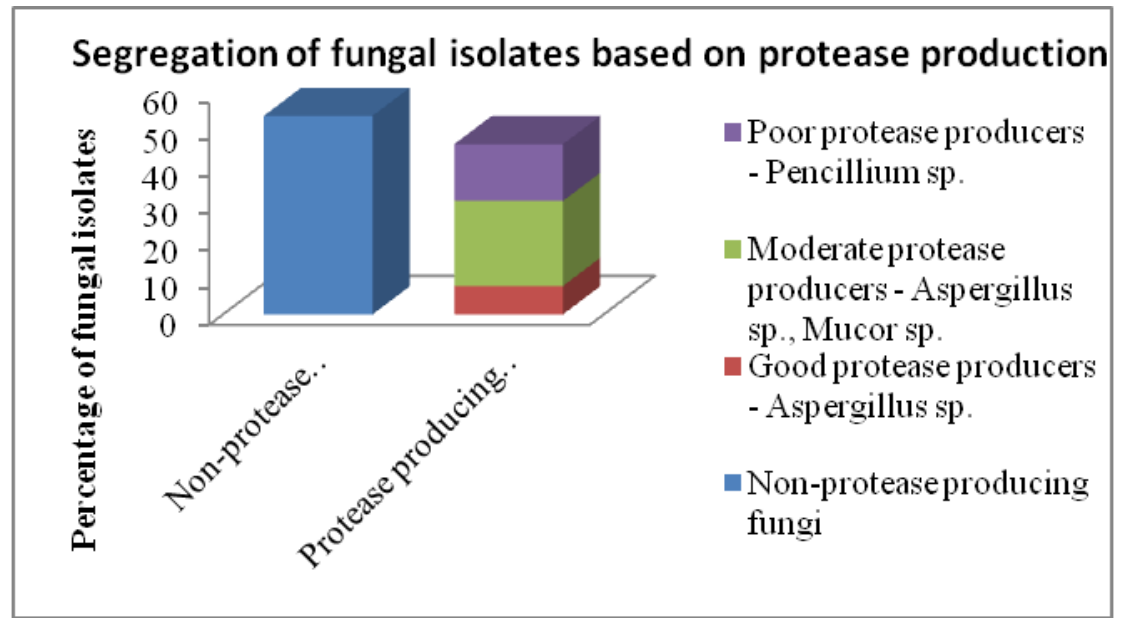

Plate.6 1.0\% Agarose gel electrophoretic PCR product of 600bp

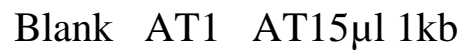

Ladder

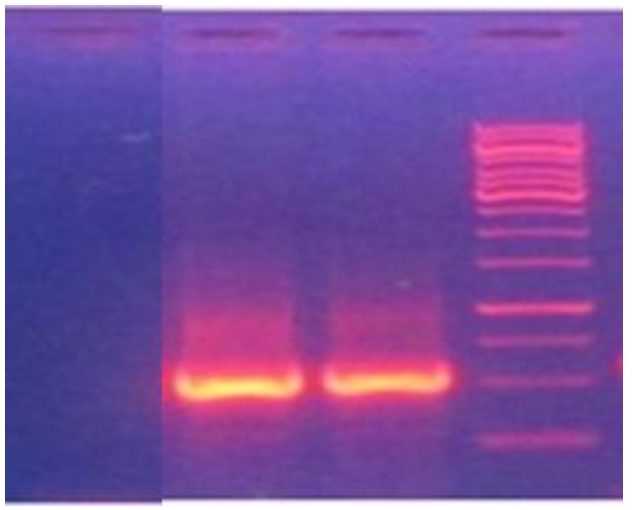

1\%agarose Gel Run At 100v

Plate.7 The aligned sequence of ITS region

\section{ITS F}

CGAGGTCACCTGGAAAATGGTTGGAAAACGTCGGCAGGCGCCGGCCAATCCTACAG AGCATGTGACAAAGCCCCATACGCTCAAGGATCGGACGCGGTGCCGCCGCTGCCTT TCGGGCCCGTCCCCCCGGAGAGGGGGACGGCGACCCAACACACAAGCCGGGCTTGA GGGCAACAATGACGCTCGGACAGGCATGCCCCCCGGAATACCAGGGGGCGCAATGT GCGTTCAAAGACTCGATGATTCACTGAATTCTGCAATTCACATTAGTTATCGCATTTC GCTGCGTTCTTCATCGATGCCGGAACCAAGAGATCCATTGTTGAAAGTTTTAACTGA TTGCATTCAATCAACTCAGACTGCACGCTTTCAGACAGTGTTCGTGTTGGGGTCTCC GGCGGGCACGGGCCCGGGGGGCAAAGGCGCCCCCCCGGCGGCCGACAAGCGGCGG GCCCGCCGAAGCAACAGGGTATAATAGACACGGATGGGAGGTTGGGCCCAAAGGA CCCGCACTCGGTAATGATCCTTCCGCAGGTTCACCTACGGAAGATTACCGAGTGCGG GTCATTGGGCCCGACCTCCCATGCGTGTCTATCATACCCTGTTGCTTCGGCGGGCCG 
CGCTAGTCGGCCGCCGGGGGGGCGCTTTGCCCCGGGGCCTGTCCGCAGACACCAAA ACGATCTATATAAGATGTCTTCAATGGTATTTGATGGGACGCATCAATAAATTCAAA CAGGACAGTGTCTGGTGCCGACGTCGACTAATA

\section{ITS R}

AGTCCTCCGCTTTATTGATATGCTTAAGTTCATCGGGTATCCCTACCTGATCTGAGGT CAACCTGGAAAAAATGGTTGGAAAACGTCGGCAGGCGCCGGCCAATCCTACAGAGC ATGTGACAAAGCCCCATACGCTCGAGGATCGGACGCGGTGCCGCCGCTGCCTTTCG GGCCCGTCCCCCCGGAGAGGGGGACGGCGACCCAACACACAAGCCGGGCTTGAGG GCAGCAATGACGGTCGGACAGGCATGCCCCCCGGAATACCAGGGGGCGCAATGTGC GTTCAAAGACTTGATGATTCAGTGAATTCTGCAATTCACATTAGTTATCGCATTTCGC TGCGTTCTTCATGGATGCCGGAACCAAGAGATCCATTGTTGAAAGTTTTAAATGATT GCATTCAATCAACTCAGACTGCACGCTTTCAGACAGTGTTGGTGTTGGGGTCTCCGG CGGGCACGGGCCCGGGGGGCAAAGGCGCCCCCCCGGCGGCCGACAAGCGGCGGGC CCGCCGAAGCAACAGGGTATAATAGACACGGATGGGAGGTGG

Plate.8 Phylogenetic tree

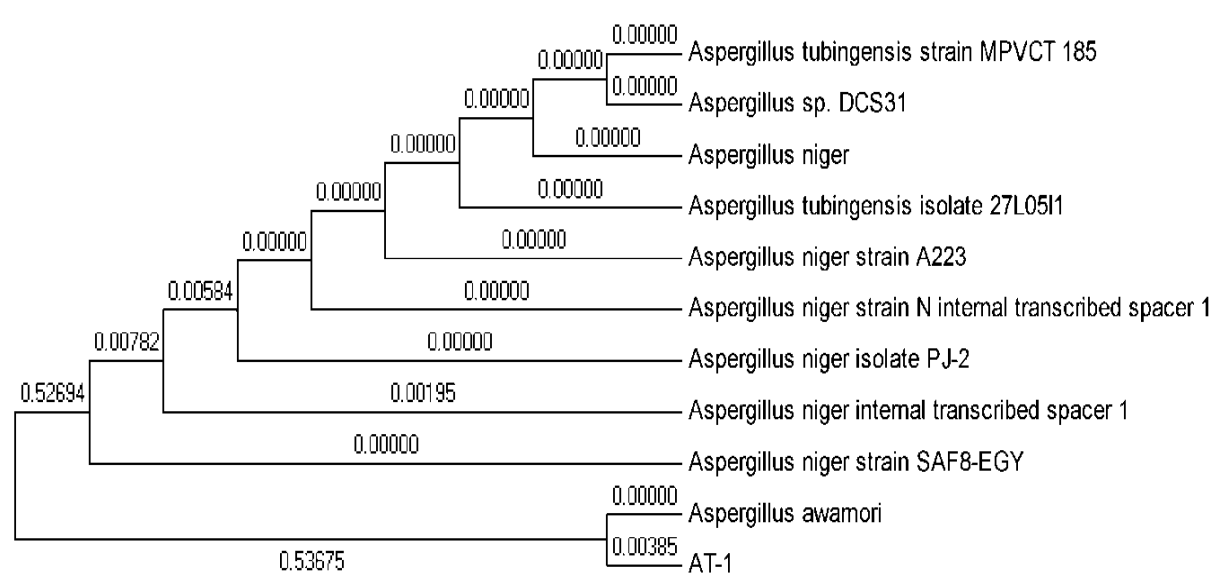

Plate.9 Effect of casein/skimmed milk concentration on hydrolysis

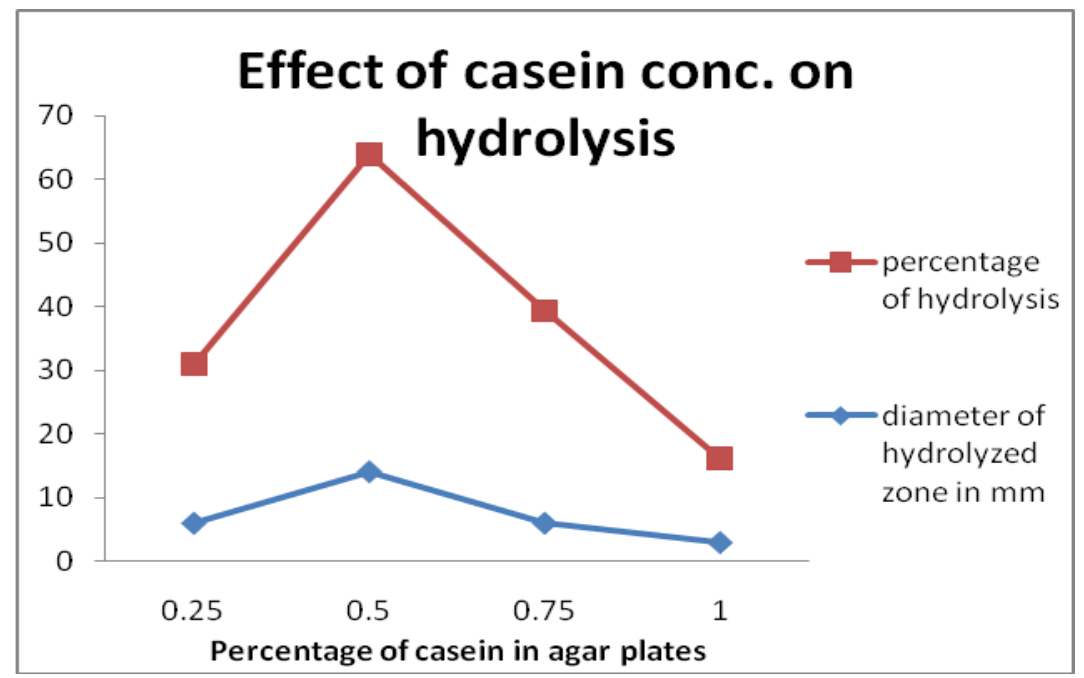


The sequence of the ITS (Plate-7) gene from fungal strain KGSR12 and that of matching sequences from 10 nucleotide sequences were aligned by using the Maximum Likelihood method based on the TamuraNei model (Shilpa et al., 2016). The tree with the highest log likelihood (-1422.4280) is shown. Initial tree(s) for the heuristic search were obtained automatically as follows.

When the number of common sites was < 100 or less than one fourth of the total number of sites, the maximum parsimony method was used; otherwise BIONJ method with MCL distance matrix was used. The analysis involved 11 nucleotide sequences. Codon positions included were 1st+2nd+3rd+Noncoding. All positions containing gaps and missing data were eliminated. There were a total of 517 positions in the final dataset. Evolutionary analyses were conducted in MEGA5 (Plate8).

\section{Effect of concentration of casein/skimmed milk in hydrolysis with Aspergillus awamori KGSR 12}

The clear zone was observed on the skimmed milk agar plates on $24 \mathrm{~h}$ culture and the zone was increased with the time period. Different concentrations of casein on the plates have showed variation in the zone of clearance. The diameter of hydrolyzed zone of the $48 \mathrm{~h}$ culture showed $0.6 \mathrm{~cm}, 1.4$ $\mathrm{cm}, 0.6 \mathrm{~cm}$ and $0.3 \mathrm{~cm}$ on the casein agar plates with concentrations $0.25 \%, 0.5 \%$, $0.75 \%$ and $1.0 \%$ respectively and their percentage of hydrolysis were $25 \%, 50 \%$, $33.3 \%$ and $13.04 \%$ successively (Plate-9). The results showed that the concentration of the casein also effects in the initiation of the protease production. But the plate with conc. of $0.5 \%$ skimmed milk showed the best result in $48 \mathrm{~h}$. This indicates that the initial phases of increasing was promoted the protease production (from $0.25 \%$ to $0.5 \%$ casein conc.) but the further increase of casein conc. was demoting the protease production (from $0.5 \%$ to $0.75 \%$ and $1.0 \%$ ).

\section{References}

Adler-Nissen, J.A. 1986. Enzymatic hydrolysis of food proteins. (Ed.) Elsevier, London.

Anju, S., Kondari, S.R. and Sarada, J. 2014. Bioprocess of silver extraction from used X-ray and MRI films. ActaBiologicalndica.3(1):561-568.

Antony, V.A.R. and Chinnamal S. K. 2015. Enzymatic degumming of silk using Bacillus species. International Journal of Science Technology \& Management. 4(1): 458-65.

Bhaskar, N., Sudeepa, E.S., Rashmi, H.N. and Selvi, A.T. 2007. Partial purification and characterization of protease of Bacillus proteolyticusCFR3001 isolated from fish processing waste and its antibacterial activities. Bioresource Technology. 98(14): 2758-2764.

Cappuccino, J.G. and Sherman, N. 2002. Microbiology: A laboratory manual. Pearson Education. 6 (4): 21-23, 138.

Feng, Z., Chen, X., Li, J. and Ren, D. 2013. An alkaline protease from Kocuriakristinae F7: properties and characterization of its hydrolysates from soy protein. European Food Research Technology. 236: 293-301.

Freddi, G., Mossotti, R. and Innocenti, R. 2003. Degumming of silk fabric with several proteases. Journal of Biotechnology 106: 101-112.

Fujiwara, N., Yamamoto, K. and Masui, A. 1991. Utilization of a thermostable alkaline protease from an alkalophilic thermophile for the recovery of silver from used X-ray film. Journal of 
Fermentation And Bioengineering. 72(4): 306-308.

Garcia-Carreno, F.L., AlbuquerqueCavalcanti, C., del Toro, M.A.N. and Zaniboni-Filho, E. 2002. Digestive proteinases of Bryconorbignyanus (Characidae, Teleostei): characteristics and effects of protein quality. Comparative Biochemistry and Physiology. 132(B): 343-352.

Gomaa, E.Z. 2013. Optimization and characterization of alkaline protease and carboxymethyl-cellulase produced by Bacillus pumillus grown on Ficusnitida wastes. Brazilian Journal of Microbiology. 44(2): 529-537.

Grant, W.D. and Jones, B.E. 2000. Alkaline environments. In: Lederberg J (Ed.) Encyclopaedia of Microbiology. Academic Press New York 1:126-133.

Gupta, R., Beg, Q.K. and Lorenz, P. 2002. Bacterial alkaline proteases: molecular approaches and industrial applications. Applied Microbiology and Biotechnology. 59: 15-32.

Horikoshi, K. 1990. Enzymes of alkaliphiles. In: Fogarty WM, Kelly CT (Ed.) Microbial Enzymes and Biotechnology. 275-294.

Jellouli, K., Bougatef, A., Manni, L., Agreb, R., Siala, R., Younes, I. and Nasri, M. 2009. Molecular and biochemical characterization of an extracellular serine-protease from Vibrio metschnikovii J1. Journal of Industrial Microbiology and Biotechnology. 36: 939-948.

Jisha, V.N., Smitha, R.B., Pradeep, S., Sreedevi, S., Unni, K.N., Sajith, S., Priji, P., Josh, M.S. and Benjamin, S. 2013. Versatility of microbial proteases. Advances in Enzyme Research. 4(3): 39-51.

Johnny, V.A.R. and Chinnammal, S.K. 2012. Degumming of silk using protease enzyme from Bacillus species. International Journal of Science and Nature. 3(1): 51-59.

Kalantzi, S., Mamma, D. and Kekos, D. 2013. Physichochemical and low stress mechanical properties of silk fabrics degummed by enzymes. Ch. 9 . http://dx.doi.org/10.5772/53730.

Kristinsson, H.G. and Rasco, B. A. 2000. Biochemical and functional properties of Atlantic salmon (Salmosalar) muscle proteins hydrolyzed with various alkaline proteases. Journal of Agricultural and Food Chemistry. 48: 657-666.

Lakshmi, B.K.M., Ratnasri, P.V., Devi, K.A. and Hemalatha, K.P.J. 2014. Screening, optimization of production and partial characterization of alkaline protease from haloalkaliphilic Bacillus $s p$. International Journal of Research in Engineering and Technology. 3(2): 535.

Lin, C.H., Wei, Y.T., and Chou, C.C. 2006. Enhanced antioxidative activity of soybean koji prepared with various filamentous fungi. Food Microbiology. 23: 628- 633 .

Lv, X.C., Huang, Z.Q., Zhang, W., Rao, P.F. and $\mathrm{Ni}, \mathrm{L} .2012$. Identification and characterization of filamentous fungi isolated from fermentation starters for Hong Qu glutinous rice wine brewing. The Journal of General and Applied Microbiology. 58: 33-42.

Ma, C., Ni, X., Chi, Z., Ma, L. and Gao, L. 2007. Purification and characterization of an alkaline protease from the marine yeast Aureobasidium pullulans for bioactive peptide production from different sources. Marine Biotechnology. 9: 343-351.

Maurer, K.H., 2004. Detergent proteases, Current Opinion in Biotechnology. 15: 330-334.

Nakiboglu, N., Toscali, D. and Yasa, I. 2001. Silver Recovery from Waste 
Photographic Films by an Enzymatic Method. Turk. J. Chem. 25:349-353.

Nasri, R., Younes, I., Lassoued, I., Ghorbel, S., Ghorbel-Bellaaj, O. and Nasri, M. 2011. Digestive Alkaline Proteases from Zosterises sorophiocephalus, Raja clavata, and Scorpaenascrofa : Characteristics and Application in Chitin Extraction. Journal of Amino Acids. 1-9.

Nosenko, T., Zhukova, Y. and Cherstva A. 2015. Sunflower protein hydrolysis degree by proteases. Scientific Works of University of Food Technologies. 62.

Nout, M.J.R. and Rombouts, F.M. 1990. Recent developments in tempe research. Journal of Applied Microbiology. 69(5): 609-633.

Ota, M., Sawa, A., Nio, N. and Ariyoshi, Y. 1999. Enzymatic ligation for synthesis of single-chain analogue of monellin by transglutaminase. Biopolymers. 50:193-200.

Pasupuleti, V.K. 1998. Applications of protein hydrolysates in industrial fermentations. Presented at industrial and fermentation microbiology symposium, LaCrosse, WI.

Pasupuleti, V.K. 2005. Manufacturing of protein hydrolysates and bioactive peptides. Presented at the annual meeting of Institute of Food Technologists, New Orleans, LA.

Pasupuleti, V.K. and Demain, A.L. 2010. Protein hydrolysates in biotechnology. (Ed.). Springer Science Business Media B.V. 13: 229. ISBN: 978-14020-6673-3.

Phalip, V., Hatsch, D., and Jeltsch, J.M. 2004. Application of yeast method for DNA extraction associated with database interrogations for the characterization of various filamentous fungi from diseased hop. Biotechnology Letters. 26: 409-413.
Pilli, R. and Siddalingeshwara, K.G. 2016. Effect of fermentation kinetics for the biosynthesis of protease from Aspergillus awamori.Journal of Drug Delivery and Therapeutics. 6(3):115118.

Proteases in the Food Industry. USP Enzyme Workshop, Gencor. July 9, 2009. Rockville, MD

Rao, M.B., Tanksale, A.M., Ghatge, M.S. and Deshpande, V.V. 1998. Molecular and biotechnological aspects of microbial proteases. Microbiology And Molecular Biology Reviews.62(3): 597-635.

Romsomsa, N., Chim-anagae, P. and Jangchud, A. 2010. Optimization of silk degumming protease production from Bacillus subtilis $\mathrm{C} 4$ using Plackett-Burman design and response surface methodology. Science Asia. 36: 118-124.

Saeki, K., Ozaki, K. and Kobayashi, T., Ito, S. 2007. Detergent alkaline proteases: enzymatic properties, genes, and crystal structures. Journal of Bioscience and Bioengineering. 103: 501-508.

Sanatan, P.T., Lomate, P.R., Giri, A.P. and Hivrale, V.K. 2013. Characterization of a chemostable serine alkaline protease from Periplaneta Americana.BMC Biochemistry. 14:32.

Sareen, R. and Mishra, P. 2008. Purification and characterization of organic solvent stable protease from Bacillus licheniformis RSP-09-37. Applied Microbiology and Biotechnology. 79: 399-405.

Sawant, R. and Nagendran, S. Protease: an enzyme with multiple industrial applications. World Journal of Pharmacy And Pharmaceutical Sciences.3(6): 568-579.

Shankar, S., More, S.V. and Laxman, R.S. 2010. Recovery of silver from waste 
X-ray film by alkaline protease from Conidiobolus coronatus. Kathmandu University Journal of Science, Engineering And Technology. 6(1): 60-69.

Shilpa, H. K., Jeevan, G.A., Basawaraj. B.D., Nilima, N.D. and Siddalingeshwara, K.G. 2016. Molecular confirmation and Role of carbon source for Biosynthesis of fibrinolytic enzyme by Aspergillus tamarii. Der Pharmacia Lettre. 8 (6):23-28.

Shivasharana, C.T. and Naik, G.R. 2012. Ecofriendly applications of thermostable alkaline protease produced from a Bacillus sp. JB-99 under Solid State Fermentation. International Journal of Environmental Sciences. 3(3): 956964.

Siddalingeshwara, K.G. and Lingappa, K. 2010. Screening and optimization of L-asparaginase- A tumour inhibitor from Aspergillusterreus through Solid State Fermentation. Journal of Advanced Scientific Research. 1(1): 55-60.
Verma, J., Kumar, D. and Saxena, S. 2016. Potential remediation of silk degumming solution a byproduct of silk industry using alkaline protease producing bacteria isolated from Northern India. Der Pharmacia Lettre. 8 (2):393-397.

Waksman, S.A. Principles of soil microbiology. Batimore. William \& Wilkins co. 1927.

White, T.J., Bruns, T., Lee, S., and Taylor, J. 1990. Amplification and direct sequencing of fungal ribosomal RNA for phylogenetics. In PCR Protocols: A Guide to Methods and Application, ed. by Inis, M. A., Gelfand, D. H., Sninsky, J. J., and White, T. J., Academic Press, San Diego, California. 315- 322 .

Wisuthiphaet, N. and Kongruang, S. 2015. Production of Fish Protein Hydrolysates by Acid and Enzymatic Hydrolysis. Journal of Medical and Bioengineering. 4(6): 466-470.

\section{How to cite this article:}

Radika Pilli and K.G. Siddalingeshwara. 2016. Rapid Confirmation and Molecular Identification of Alkaline Protease Producing Aspergillus awamori through Submerged Fermentation. Int.J.Curr.Microbiol.App.Sci. 5(10): 1114-1124. doi: http://dx.doi.org/10.20546/ijcmas.2016.510.117 